\title{
Study on Processing Technology of Functional Brown Rice Enzyme Cake
}

\author{
Yuanyuan Liu, Jianyuan Ning, Xingyue Cui, Junling Wang, Chuang Yang*
}

Jilin Agricultural Science and Technology University, Jilin, Jilin, 132101

${ }^{*}$ Corresponding author

Keywords: Functional; brown rice enzyme; processing technology

\begin{abstract}
In this paper, brown rice enzyme was used as the main raw material, and high-gluten wheat flour, baking powder, cake oil and other auxiliary materials were added to study the processing technology of brown rice enzyme cake. The optimum technological parameters of brown rice enzyme cake were determined by single factor experiment and response surface test.
\end{abstract}

\section{Introduction}

"Brown rice enzyme" is a mixed enzyme system that is produced by microorganisms using the nutrients in brown rice in the main nutrient sources of brown rice - germ and alfalfa [1]. The brown rice enzyme obtained after fermentation of brown rice not only preserves the original nutrients in brown rice, but also improves the taste by self-metabolism, increases the nutritional value of brown rice, and improves its health care function [2]. In addition, the enzyme contains carotene, vitamins, proteolytic enzymes, amylolytic enzymes, lipolytic enzymes, and abundant protein, crude fiber, saccharide, iron, calcium, sodium and other ingredients to help nutrients absorb quickly and improve human immunity. It can also activate cells, promote metabolism, and use enzymes in combination with other foods, and can also play an incredible magical effect [3].

In this paper, brown rice enzyme is used as a food additive in baked goods, and its improvement effect on food processing characteristics is preliminarily discussed, which lays a foundation for the further application of brown rice enzyme in food [4].

\section{Materials and methods}

Brown rice, active dry yeast, honey, white sugar, citric acid, high-gluten wheat flour, baking powder, cake oil and butter are all commercially available, and the laboratory is provided with ionized water.

ACS-30 electronic pricing balance Guangdong Xiangshan Weighing Apparatus Group Co., Ltd.; B20-G mixer Guangdong Henglian Food Machinery Co., Ltd.; SPX-150B-Z type biochemical incubator Shanghai Boxun Industrial Co., Ltd. Medical Equipment Factory; FKB food electric oven Beijing Shunmai Oven Co., Ltd.

Carefully select high-quality brown rice, remove moldy materials and impurities, accurately weigh $100 \mathrm{~g}$ of each selected brown rice, wash it and seal it with $0.1 \mathrm{mmol} / \mathrm{L} \mathrm{NaClO}$ solution for $10 \mathrm{~min}$ under sealed condition and rinse. The washed brown rice was immersed in $0.5 \mathrm{mmol} / \mathrm{L}$ of $\mathrm{CaCl} 2$ and immersed at $32{ }^{\circ} \mathrm{C}$ for 24 hours. Drain the water and place it on a perforated partition with sterile gauze. The surface is covered with wet gauze. The lower end of the partition has a matching water tank [5]. The anaerobic treatment was carried out for 6 hours after germination culture for 32 hours in an incubator at a constant temperature of $28{ }^{\circ} \mathrm{C}$ and a relative humidity of $90 \%$ to $95 \%$, and the germination was terminated when the brown rice buds grew to about $0.5 \mathrm{~cm}$. After rinsing, it is dried, pulverized, filtered through a 100 mesh sieve, and sterilized for 30 minutes [6].

Weigh two $0.5 \mathrm{~g}$ active dry yeast in two test tubes, add $7.5 \mathrm{ml}$ of water to the two test tubes, then put them into the beaker, add water to make the liquid in the tube not $5 \sim 6 \mathrm{~mm}$, put into 40 After 20 minutes of activation in a ${ }^{\circ} \mathrm{C}$ water bath, it was taken out for use.

Weigh $8 \mathrm{~g}$ honey, measure $13 \mathrm{ml}$ yeast activation solution and $100 \mathrm{ml}$ pure water in the beaker. 
Add $100 \mathrm{ml}$ water, $8 \mathrm{~g}$ honey, $13 \mathrm{ml}$ yeast activation solution and $10 \mathrm{~g}$ germinated brown rice powder to the large culture dish under the prepared super bacteria table. Then, the large culture dish was placed in a constant temperature $30^{\circ} \mathrm{C}$ incubator for 4 hours, and then taken out after 4 hours [7].

Study the cake production process, add brown rice enzyme, high-gluten wheat flour, baking powder and additives, mix the dough, and bake the oil.

The five students studied the sensory evaluation of the roasted brown rice enzyme cake samples in strict accordance with the sensory evaluation criteria, and scored the color, shape, sweetness, internal structure and taste. The sensory scoring criteria are shown in Table 1.

Table 1 Response Surface Analysis Scheme and Results Table

\begin{tabular}{|c|c|c|c|c|c|c|}
\hline $\begin{array}{c}\text { Standard } \\
\text { order }\end{array}$ & $\begin{array}{l}\text { Operation } \\
\text { sequence }\end{array}$ & A & B & $\mathrm{C}$ & $\mathrm{D}$ & $\begin{array}{c}\text { Sensory } \\
\text { score }\end{array}$ \\
\hline 12 & 1 & 1.000 & 0.000 & 0.000 & 1.000 & 86 \\
\hline 28 & 2 & 0.000 & 0.000 & 0.000 & 0.000 & 98 \\
\hline 14 & 3 & 0.000 & 1.000 & -1.000 & 0.000 & 80 \\
\hline 23 & 4 & 0.000 & -1.000 & 0.000 & 1.000 & 72 \\
\hline 10 & 5 & 1.000 & 0.000 & 0.000 & -1.000 & 83 \\
\hline 6 & 6 & 0.000 & 0.000 & 1.000 & -1.000 & 86 \\
\hline 22 & 7 & 0.000 & 1.000 & 0.000 & -1.000 & 81 \\
\hline 17 & 8 & -1.000 & 0.000 & -1.000 & 0.000 & 91 \\
\hline 7 & 9 & 0.000 & 0.000 & -1.000 & 1.000 & 87 \\
\hline 8 & 10 & 0.000 & 0.000 & 1.000 & 1.000 & 93 \\
\hline 16 & 11 & 0.000 & 1.000 & 1.000 & 0.000 & 85 \\
\hline 1 & 12 & -1.000 & -1.000 & 0.000 & 0.000 & 92 \\
\hline 11 & 13 & -1.000 & 0.000 & 0.000 & 1.000 & 95 \\
\hline 24 & 14 & 0.000 & 1.000 & 0.000 & 1.000 & 85 \\
\hline 27 & 15 & 0.000 & 0.000 & 0.000 & 0.000 & 98 \\
\hline 5 & 16 & 0.000 & 0.000 & -1.000 & -1.000 & 84 \\
\hline 13 & 17 & 0.000 & -1.000 & -1.000 & 0.000 & 68 \\
\hline 26 & 18 & 0.000 & 0.000 & 0.000 & 0.000 & 98 \\
\hline 20 & 19 & 1.000 & 0.000 & 1.000 & 0.000 & 89 \\
\hline 29 & 20 & 0.000 & 0.000 & 0.000 & 0.000 & 98 \\
\hline 15 & 21 & 0.000 & -1.000 & 1.000 & 0.000 & 73 \\
\hline 18 & 22 & 1.000 & 0.000 & -1.000 & 0.000 & 82 \\
\hline 4 & 23 & 1.000 & 1.000 & 0.000 & 0.000 & 81 \\
\hline 19 & 24 & -1.000 & 0.000 & 1.000 & 0.000 & 95 \\
\hline 25 & 25 & 0.000 & 0.000 & 0.000 & 0.000 & 98 \\
\hline 2 & 26 & 1.000 & -1.000 & 0.000 & 0.000 & 84 \\
\hline 3 & 27 & -1.000 & 1.000 & 0.000 & 0.000 & 90 \\
\hline 9 & 28 & -1.000 & 0.000 & 0.000 & -1.000 & 92 \\
\hline 21 & 29 & 0.000 & -1.000 & 0.000 & -1.000 & 72 \\
\hline
\end{tabular}

When the amount of baking powder is fixed at $5 \mathrm{~g}$, the amount of high-gluten wheat flour is $300 \mathrm{~g}$, the amount of cake oil is $40 \mathrm{~g}$, and the amount of brown rice enzyme is $2 \mathrm{ml}, 3 \mathrm{ml}, 4 \mathrm{ml}, 5 \mathrm{ml}$, and $6 \mathrm{ml}$, the amount of brown rice enzyme added is investigated. The effect of the quality of brown rice enzyme cake;

The amount of high-gluten wheat flour was investigated under the conditions of a fixed amount of $4 \mathrm{ml}$ of brown rice enzyme, $5 \mathrm{~g}$ of baking powder, and $40 \mathrm{~g}$ of cake oil, and the amount of high-gluten wheat flour was 200 g, 250 g, 300 g, 350 g, and 400 g, respectively. The effect on the quality of brown rice enzyme cake;

When the amount of brown rice enzyme added was $4 \mathrm{ml}$, the amount of high-gluten wheat flour was $300 \mathrm{~g}$, the amount of cake oil was $40 \mathrm{~g}$, and the amount of baking powder was $3 \mathrm{~g}, 4 \mathrm{~g}, 5 \mathrm{~g}, 6 \mathrm{~g}, 7 \mathrm{~g}$, 
the amount of baking powder was determined. The effect of the quality of brown rice enzyme cake;

In the condition that the amount of brown rice enzyme is $4 \mathrm{ml}$, the amount of baking powder is $5 \mathrm{~g}$, the amount of high-gluten wheat flour is $300 \mathrm{~g}$, and the amount of cake oil is $20 \mathrm{~g}, 30 \mathrm{~g}, 40 \mathrm{~g}, 50 \mathrm{~g}$, respectively, the amount of cake oil added to the quality of brown rice enzyme cake is investigated.

The amount of brown rice enzyme added (ml), the amount of high-gluten wheat flour (g), the amount of baking powder (g), and the amount of cake oil added (g) were investigated. Under each factor, three levels were selected for the response surface test, and the sensory quality score was used as the evaluation index to determine the optimal addition amount of the brown rice enzyme cake.

\section{Results and analysis}

As the amount of brown rice enzyme added gradually increased, the influence on the sensory quality of brown rice enzyme cake gradually increased. When the amount of brown rice enzymes continues to increase, the sensory score of the brown rice enzyme cake will drop drastically. Therefore, the optimal addition amount of brown rice enzyme is $6 \mathrm{ml}$.

With the increasing amount of high-gluten wheat flour, the influence on the sensory quality of brown rice enzyme cake is gradually increasing. When the amount of high-gluten wheat flour continues to increase, the sensory score of the brown rice enzyme cake will gradually decrease. Therefore, the optimal addition amount of high-gluten wheat flour is $200 \mathrm{~g}$.

As the amount of baking powder added gradually increased, the influence on the sensory quality of brown rice enzyme cake gradually increased. When the amount of baking powder increased continuously, the sensory score of brown rice enzyme cake showed a slow downward trend. Therefore, the optimal addition amount of high-gluten wheat flour was $10 \mathrm{~g}$.

With the increasing amount of cake oil added, the influence on the sensory quality of brown rice enzyme cake is gradually increasing. When the amount of cake oil added continued to increase, the sensory score of brown rice enzyme cake showed a slow downward trend. Therefore, the optimal addition amount of high-gluten wheat flour was $40 \mathrm{~g}$.

The multiple regression equations with the sensory score as the objective function are obtained as follows:

$\mathrm{Y}=96.00-3.00 \mathrm{~A}+2.42 \mathrm{~B}+2.00 \mathrm{C}+0.92 \mathrm{D}+0.25 \mathrm{AB}+1.75 \mathrm{AC}+1.00 \mathrm{AD}-0.50 \mathrm{BC}-0.50 \mathrm{BD}+0.25 \mathrm{CD}-0.5$ $4 \mathrm{~A}^{2}-10.92 \mathrm{~B}^{2}-6.04 \mathrm{C}^{2}-5.92 \mathrm{D}^{2}$

The model selected for the test was extremely significant $(P<0.01)$. It can be seen from the $P$ value that the influence of each factor on the score of the brown rice enzyme cake is $D>C>B>A$. Among them, the quadratic terms $\mathrm{C}^{2}$ and $\mathrm{D}^{2}$ are significant, and the correlation coefficient $\mathrm{R}^{2}=0.8583$, indicating that the model fits well. $\mathrm{R}_{\text {Adj }}^{2}=0.7166$, indicating that the experimental error is small, indicating that the model can be used to analyze and predict the sensory of brown rice enzyme cake.

According to the response surface analysis, the interaction between the optimal parameters and the parameters can be visually displayed. According to the above simulated quadratic multiple regression model and its analysis of variance, the corresponding response surface and contour are obtained. The closer the contour line is to the ellipse, the stronger the interaction and the closer to the circle, indicating that the interaction is weaker. According to the results of the response surface, the best process conditions were obtained by software analysis: $4.00 \mathrm{ml}$ of brown rice enzyme, $204.93 \mathrm{~g}$ of high-gluten wheat flour, $10.03 \mathrm{~g}$ of baking powder, and $39.90 \mathrm{~g}$ of cake oil.

In order to verify the rationality and feasibility of the test operation, in the actual operation, the optimization conditions of the response surface analysis method were adjusted to $4 \mathrm{ml}$ of brown rice enzyme, $205 \mathrm{~g}$ of high-gluten wheat flour, and $10 \mathrm{~g}$ of baking powder, cake oil. The addition amount is $40 \mathrm{~g}$. Under this condition, the average of the repeated experiments of the brown rice enzyme cake is divided into 96 points, which proves that the regression equation of the response surface optimized brown rice enzyme cake is well fitted and has high accuracy. 


\section{Conclusion}

In this experiment, brown rice enzyme was used as the main raw material, and high-gluten wheat flour, baking powder, cake oil and other auxiliary materials were added to study the processing technology of brown rice enzyme cake. The optimum process parameters of brown rice enzyme cake were determined by single factor experiment and response surface test analysis. The brown rice enzyme cake processed by this processing technology is bright and lustrous, the block shape is full and positive, the taste is soft and sweet, and has the unique flavor of the cake, and has certain nutritional value and practical value.

\section{Acknowledgements}

Fund Project: Fund Project: Jilin Agricultural Science and Technology University 2018 National Science and Technology Innovation and Entrepreneurship Training Program, Project No.: 201811439037

\section{References}

[1] Liu Yuehao, Ren Limin. Nutritional Value of Brown Rice and Its Application in Food [J]. Grain Processing, 2004(2): 18-20.

[2]Wang Zhongli, Zhao Xiaohong. Nutritional Value of Brown Rice and Its Development and Application of New Foods [J]. China Rice, 2005(5): 47-48.

[3] Lu Mei, Qi Sen, Jia Lei, et al. Fermentation process of brown rice enzymes [J] . Food Research and Development, 2007, 10 (28): 111-113.

[4] HEINEMQNN RJB, FANGUNDES PL, PINTO EA, etal. Compara-tive study of nutrient composition of commercial brown, parboiled and milled rice from Brazil [J]. J Food Compos, Anal, 2005, 18(4): 287- 296.

[5] Jin Zenghui. Development of Brown Rice Enzyme and Its Products [J]. Grain and Oil, 2002 (4): $14-16$.

[6] Kang Binbin. Preparation of germinated brown rice and its lactic acid fermentation process [D]. Master's thesis of Fujian Agriculture and Forestry University, 2006.

[7] Li Zhijiang, Niu Guangcai, Lu Baoxin, et al. Study on fermentation conditions of brown rice enzyme fermentation [J]. China Brewing, 2008 (22): 65-67.

[8] Zhou Huiming, Zhang Minping. Study on Functional Components in Brown Rice [J].Food Science and Technology, 2002(5):17-19. 